\title{
Pertumbuhan dan Produktivitas Tanaman Kedelai diantara Beberapa Varietas Jagung Hibrida dengan Jarak Tanam Berbeda
}

\author{
Growth and Productivity of Soybean Plants among Several Hybrid Corn Varieties with \\ Different Spacing
}

\author{
Sution ${ }^{1}$, Akhmad Musyafak ${ }^{2}$, Agus Subekti ${ }^{3}$, Sari Nurita ${ }^{4}$, Laurensius Lehar ${ }^{5 *}$ \\ ${ }^{1,2,3,4}$ Balai Pengkajian Teknologi Pertanian (BPTP) Kalimantan Barat, Indonesia \\ ${ }^{5}$ Politeknik Pertanian Negeri Kupang, NTT, Indonesia \\ *Correspondence Author: laurensiusl@yahoo.co.id
}

\begin{abstract}
ABSTRAK
Penelitian ini bertujuan untuk mengetahui pengaruh pertumbuhan dan produksi kedelai yang ditanam diantara beberapa varietas jagung hibrida dengan jarak tanaman berbeda. Rancangan penelitian menggunakan Split Plot Desain (RPT), sebagai petak utama jarak tanam kedelai $30 \mathrm{~cm} \times 15 \mathrm{~cm}$ dengan jumlah kedelai 5 baris $(180 \mathrm{~cm})$ dan jumlah kedelai 7 baris $(240 \mathrm{~cm})$. Sedangkan sebagai anak petak yaitu verietas jagung hibrida yaitu Pioneer 35, Bima 19, JH 27, Bima 2 dan Nasa 29, yang ditanam dengan jarak tanam $60 \mathrm{~cm} \times 12,5 \mathrm{~cm}$. Sehingga terdapat 10 kombinasi perlakuan, kemudian diulang sebanyak 3 kali. Hasil penelitian terhadap komponen pertumbuhan tanaman yaitu Tinggi tanaman kedelai menunjukkan bahwa kedelai ditanam diantara jagung hibrida varietas $\mathrm{JH} 27(112,15 \mathrm{~cm})$ dan Bima $2(107,85 \mathrm{~cm})$ tertinggi dibanding kedelai ditanam diantara varietas jagung yang lainnya. Variabel pengamatan terhadap komponen hasil menunjukkan bahwa jumlah polong per tanaman dan jumlah polong isi tertinggi pada perlakuan kedelai ditanam diantara varietas jagung hibrida $\mathrm{JH} 27$ jarak tanam 7 baris masing-masing 46,64 polong dan 44,53 polong. Sedangkan jumlah biji per tanaman dan jumlah biji isi per tanaman tertinggi pada perlakuan kedelai ditanam diantara jagung hibrida varietas Bima 2 dan Nasa 29 dengan jarak tanam 7 baris masing-masing 73,33 biji, 71,14 biji dan 71,64 biji, 69,61 biji. Bobot 100 butir tertinggi pada perlakuan kedelai ditanam diantara jagung hibrida varietas Pioner 35 (14,70 g), Bima 2 (14,67 g) dan Nasa 29 (14,42 g). kedelai ditanam diantara varietas jagung hibrida Bima 2, JH 27 dan Nasa 29 nyata berpengaruh terhadap produksi dan berpengaruh nyata terhadap kedelai ditanam diantara jagung hibrida varietas Bima 19 dan Pioner 35.
\end{abstract}

Kata Kunci : Jagung Hibrida, Jarak Tanam, Produktivitas kedelai, Tumpangsari.

\section{ABSTRACT}

This study aims to determine the effect of growth and production of soybeans grown among several varieties of hybrid corn with different plant spacing. The study design uses Split Plot Design (SPD), as the main plot of the spacing of 5 rows of soybean $(180 \mathrm{~cm})$ and spacing of 7 rows of soybeans $(240 \mathrm{~cm})$. While as subplots, hybrid corn varieties are Pioneer 35, Bima 19, JH 27, Bima 2 and Nasa 29, so there are 10 treatment combinations, then repeated 3 times. The results showed that the highest number of pods per plant and the number of filled pods in the soybean treatment were planted among JH 27 hybrid corn varieties with the spacing of 7 rows of 46.64 and 44.53 pods respectively. While the highest number of seeds per plant and number of seeds per plant in the soybean treatment was planted between hybrid maize varieties of Bima 2 and Nasa 29 with 7 rows spacing of 73.33 seeds, 71.14 seeds, and 71.64 seeds, 69 , 61 seeds. Whereas the highest soybean crop in the soybean treatment was planted among hybrid corn varieties JH 27 $(112.15 \mathrm{~cm})$ and Bima $2(107.85 \mathrm{~cm})$. The highest weight of 100 grains in the soybean treatment was planted among hybrid pioneer varieties 35 (14.70 g), Bima 2 (14.67 g) and NASA 29 (14.42 g). soybeans grown between hybrid corn varieties Bima 2, JH 27 and Nasa 29 significantly affect production and significantly affect soybeans grown between hybrid corn varieties Bima 19 and Pioneers 35.

Keywords: Hybrid Maize, Planting Distance, Soybean Productivity, Intercropping.

\section{PENDAHULUAN}

Kedelai (Glycine max L.) merupakan salah satu komoditas utama kacangkacangan yang menjadi andalan nasional karena merupakan sumber protein nabati penting untuk diversifikasi pangan dalam mendukung ketahanan pangan nasional.
Kedelai mempunyai kandungan protein nabati, karbohidrat dan lemak yang sangat tinggi, mempunyai kandungan fosfor, besi, kalsium, vitamin B dengan komposisi asam amino lengkap potensial untuk pertumbuhan tubuh manusia dan juga mengandung asamasam tak jenuh yang dapat mencegah 
timbulnya arteri sclerosis yaitu terjadinya pengerasan pembuluh nadi (Khotbawan et al., 2015). Kedelai sebagai salah satu sumber protein nabati menjadi pilihan yang lebih terjangkau dibandingkan protein hewani (Yuwariah et al., 2017).

Tumpangsari dapat dilakukan antara tanaman semusim dengan tanaman semusim yang saling menguntungkan, misalnya antara jagung dan kacang-kacangan (Marliah et al., 2010). Salah satu cara dalam meningkatkan efisiensi lahan adalah melalui pola tanam intercropping (tumpangsari) karena mengoptimalkan pemanfaatan cahaya, air dan hara, mengontrol gulma, hama dan penyakit, memperbaiki kesuburan tanah melalui fiksasi $\mathrm{N}$ yang berasal dari legume serta merupakan jalur menuju pertanian yang berkelanjutan (Lithourgidis et al. 2011). Tanaman yang ditanam secara tumpangsari sebaiknya mempunyai umur atau periode pertumbuhan yang tidak sama, karena mempunyai perbedaan kebutuhan terhadap faktor lingkungan seperti air, kelembaban, cahaya dan unsur hara tanaman, karena itu akan mempengaruhi pertumbuhan dan hasil kedua tanaman tersebut.

Penelitian ini dilakukan dengan maksud mengetahui pengaruh pertumbuhan dan produksi kedelai yang ditanam diantara beberapa varietas jagung hibrida dengan jarak tanam yang berbeda.

\section{METODE PENELITIAN}

Penelitian ini dilaksanakan di wilayah perbatasan Kabupaten Sanggau tepatnya di Desa Kenaman, Kec. Sekayam, Kab. Sanggau. Pada bulan Oktober 2018 Februari 2019. Penanaman kedelai dilakukan dengan cara tugal jarak tanam antar baris 30 $\mathrm{cm}$ dalam baris $15 \mathrm{~cm}$, sedangkan jarak kedelai diantara tanaman jagung sebagai perlakuan yaitu 5 baris $(180 \mathrm{~cm})$ dan 7 baris $(240 \mathrm{~cm})$. varietas kedelai yang ditanam yaitu Dena 1. Pemupukan dilakukan pada umur 14 hst dengan dosis TSP $90 \mathrm{~kg} / \mathrm{ha}$ dan NPK 1616-16 sebanyak $120 \mathrm{~kg} / \mathrm{ha}$ aplikasi dilakukan dengan cara disebar pada baris tanaman. Pengolahan lahan dilakukan dengan olah tanah sempurna yaitu dibajak dan dirotari. Setelah umur kedelai 3 minggu setelah tanam kemudian disusul dengan penanaman jagung. Jarak tanam jagung antar baris 60 $\mathrm{cm}$ dalam baris $12,5 \mathrm{~cm}$. Penanaman jagung 2 biji/lubang tanam, kemudian ditutup dengan pupuk kandang $\pm \quad 25-50$ g/lubang. Pemupukan dilakukan 2 kali yaitu umur 14 hst (urea $50 \mathrm{~kg} / \mathrm{ha}$, TSP $150 \mathrm{~kg} / \mathrm{ha}$ dan NPK 16-16-16 $200 \mathrm{~kg} / \mathrm{ha}$ ), pemupukan kedua umur 30 hst (100 kg/ha, dan NPK 16-16-16 sebanyak $250 \mathrm{~kg} / \mathrm{ha})$.

Penelitian ini menggunakan Rancangan Petak Terbagi (split plot design). Petak utama yaitu B1 = kedelai ditanam 5 baris $(180 \mathrm{~cm})$, dan $\mathrm{B} 2=$ kedelai ditanam 7 baris $(240 \mathrm{~cm})$. Anak petak adalah varietas jagung hibrida yang terdiri dari $\mathrm{V} 1=$ Pioneer $35, \mathrm{~V} 2=$ Bima 19, V3 = JH 27, V4 = Bima 2 dan V5 = Nasa 29. Sehingga kombinasi dari kedua perlakuan tersebut sebanyak 10 kombinasi yang diulang sebanyak 3 kali. Sehingga menghasilkan 30 petak perlakuan.

Variabel pengamatan kedelai yaitu (1) tinggi tanaman (cm), (2) jumlah cabang per tanaman (cabang), (3) polong per tanaman (polong), (4) jumlah polong isi per tanaman (polong), (5) presentase polong rusak (\%), (6) jumlah biji isi per tanaman (biji), (7) jumlah biji per tanaman (biji), (8) presentase biji rusak per tanaman (\%), (9) bobot 100 butir (g) dan (10) produktivitas tanaman (kg/ha). Data dianalisis dengan menggunakan uji $\mathrm{F}$ dan apabila menunjukkan perbedaan yang nyata, maka pengujian dilanjutkan dengan BNT tarap 5\%, untuk mengetahui beda pengaruh antar perlakuan.

\section{HASIL DAN PEMBAHASAN}

\section{Komponen Pertumbuhan Tanaman Kedelai}

Hasil analisis ragam terhadap tinggi tanaman dan jumlah cabang per tanaman tidak terdapat interaksi antara perlakuan kedelai ditanam diantara beberapa varietas jagung hibrida dengan jarak tanam kedelai 57 baris. Pada masing-masing perlakuan menunjukkan bahwa kedelai ditanam diantara beberapa varietas jagung hibrida berpengaruh nyata terhadap tinggi tanaman, sedangkan jarak tanam kedelai 5-7 baris tidak berpengaruh nyata pada perlakuan tinggi tanaman. Jumlah cabang per tanaman tidak berpengaruh nyata pada masingmasing perlakuan kedelai ditanam diantara varietas jagung hibrida dan jarak tanam kedelai 5-7 baris. (Tabel 1). 
Tabel 1. Rata-rata tinggi tanaman dan jumlah cabang per tanaman akibat pengaruh perlakuan kedelai ditanam dianatara beberapa varietas jagung hibrida dan jarak tanam kedelai 57 baris.

\begin{tabular}{lcc}
\hline \multirow{2}{*}{ Perlakuan } & \multicolumn{2}{c}{ Variabel Pengamatan } \\
\cline { 2 - 3 } & Tinggi $(\mathrm{cm})$ & $\begin{array}{c}\text { Jlh Cabang per } \\
\text { Tanaman }\end{array}$ \\
\hline Kedelai Diantara Var Pioneer 35 & $94.80 \mathrm{c}$ & $1.03 \mathrm{a}$ \\
Kedelai Diantara Var Bima 19 & $100.70 \mathrm{bc}$ & $2.47 \mathrm{a}$ \\
Kedelai Diantara Var JH 27 & $112.15 \mathrm{a}$ & $1.49 \mathrm{a}$ \\
Kedelai Diantara Var Bima 2 & $107.85 \mathrm{ab}$ & $1.35 \mathrm{a}$ \\
Kedelai Diantara Var Nasa 29 & $99.72 \mathrm{bc}$ & $1.36 \mathrm{a}$ \\
\hline BNT 5 \% & 10,47 & tn \\
\hline Kedelai 5 baris & $95.97 \mathrm{a}$ & $1.26 \mathrm{a}$ \\
Kedelai 7 baris & $110.11 \mathrm{a}$ & $1.82 \mathrm{a}$ \\
\hline BNT 5\% & tn & tn
\end{tabular}

Keterangan : Angka didampingi huruf yang sama pada kolom yang sama berarti tidak berbeda nyata menurut uji BNT $5 \%$.

Pada Tabel 1 diatas menunjukkan bahwa tanaman tertinggi pada perlakuan kedelai ditanam diantara jagung hibrida varietas $\mathrm{JH} 27(112,15 \mathrm{~cm})$, namun tidak berbeda dengan kedelai ditanam diantara jagung varietas Bima $2(107,85 \mathrm{~cm})$. Sedangkan kedelai ditaman dengan jarak 5-7 baris diantara beberapa varietas jagung hibrida tidak terjadi perbedaan pada tinggi tanaman.

Data jumlah cabang per tanaman pada Tabel 1 diatas menunjukkan bahwa tidak terjadi perbedaan kedelai ditanam diantara beberapa varietas jagung hibrida. Demikian juga kedelai ditaman 5-7 baris diantara varietas jagung hibrida tidak terjadi perbedaan pada jumlah cabang per tanaman.

\section{Komponen Produksi Tanaman Kedelai}

Berdasarkan Hasil analisis ragam menunjukkan bahwa terdapat interaksi komponen produksi tanaman kedelai yang ditanaman diantara varietas jagung hibrida dengan jarak tanam kedelai 5-7 baris terhadap jumlah polong per tanaman, jumlah polong isi per tanaman, presentase polong rusak, jumlah biji per tanaman, jumlah biji isi per tanaman dan presentase biji rusak per tanaman (Tabel 2).

Data jumlah polong kedelai per tanaman pada Tabel 2 dibawah memperlihatkan bahwa kedelai ditanam diatara jagung varietas $\mathrm{JH} 27$ dengan jarak tanam kedelai 7 baris mempunyai jumlah polong tertinggi (46,64 polong), sedangkan kedelai ditanam diantara jagung varietas Pioneer 35 dengan jarak tanam kedelai 5 baris mumpunyai jumlah polong per tanaman paling sedikit (18,67 polong).

Pada Tabel 2 dibawah menunjukkan bahwa jumlah polong isi per tanaman tertinggi pada perlakuan kedelai ditanam diantara jagung varietas $\mathrm{JH} \quad 27 \quad(44,53$ polong) dan Bima 2 (41,06 polong) dengan jarak tanam kedelai 7 baris. Sedangkan jumlah polong isi paling sedikit pada perlakuan kedelai ditanam diantara jagung varietas Pioneer 35 dengan jarak tanam kedelai 5 dan 7 baris (17,50 polong dan 19,03 polong).

Data presentase polong rusak pada Tabel 2 memperlihatkan bahwa kedelai ditanam diatara jagung varietas Pioneer 35 dengan jarak tanam kedelai 5-7 baris mempunyai presentase polong rusak paling tinggi $(5,20 \%-5,24 \%)$. Sedangkan presentase polong rusak paling sedikit pada perlakuan kedelai ditanam diantara jagung varietas JH 27, Bima 2 dan Nasa 29 dengan jarak tanam kedelai 5 baris masing-masing $(2,15 \%, 1,80 \%$ dan $2,01 \%)$. Polong hampa atau keriput dapat disebabkan waktu panen yang lebih awal dari waktu panen seharusnya (Herliana et al., 2015) 
Tabel 2. Rata-rata jumlah polong per tanaman, jumlah polong isi per tanaman, presentase polong rusak, jumlah biji per tanaman, jumlah biji isi per tanaman dan presentase biji rusak per tanaman akibat pengaruh perlakuan kedelai ditanam dianatara beberapa varietas jagung hibrida dan jarak tanam kedelai 5-7 baris.

\begin{tabular}{|c|c|c|c|c|c|c|}
\hline \multirow[b]{2}{*}{ Perlakuan } & \multicolumn{6}{|c|}{ Variabel Pengamatan } \\
\hline & $\begin{array}{l}\text { Jumlah } \\
\text { polong per } \\
\text { tanaman } \\
\text { (polong) }\end{array}$ & $\begin{array}{l}\text { Jumlah } \\
\text { polong isi per } \\
\text { panaman } \\
\text { (polong) }\end{array}$ & $\begin{array}{l}\text { Presentase } \\
\text { polong } \\
\text { rusak }(\%)\end{array}$ & $\begin{array}{l}\text { Jumlah } \\
\text { biji per } \\
\text { tanaman } \\
\text { (biji) }\end{array}$ & $\begin{array}{l}\text { Jumlah biji } \\
\text { isi per } \\
\text { tanaman } \\
\text { (biji) }\end{array}$ & $\begin{array}{c}\text { Presentase } \\
\text { biji rusak } \\
\text { per tanaman } \\
(\%)\end{array}$ \\
\hline $\begin{array}{l}\text { Kedelai } 5 \text { Baris + } \\
\text { Diantara Var } \\
\text { Pioneer } 35\end{array}$ & $18.67 \mathrm{c}$ & $17.50 \mathrm{f}$ & $5.20 \mathrm{a}$ & $31.28 \mathrm{f}$ & $30.19 \mathrm{f}$ & $3.30 \mathrm{~d}$ \\
\hline $\begin{array}{l}\text { Kedelai } 5 \text { Baris }+ \\
\text { Diantara Var Bima } \\
19\end{array}$ & $25.53 \mathrm{bc}$ & $24.56 \mathrm{~d}$ & $3.79 \mathrm{~d}$ & $46.00 \mathrm{bc}$ & $44.31 \mathrm{bc}$ & $3.30 \mathrm{~d}$ \\
\hline $\begin{array}{l}\text { Kedelai } 5 \text { Baris }+ \\
\text { Diantara Var JH } 27\end{array}$ & $24.42 \mathrm{bc}$ & $23.78 \mathrm{de}$ & $2.15 \mathrm{f}$ & $37.17 \mathrm{df}$ & $35.31 \mathrm{df}$ & $5.87 \mathrm{a}$ \\
\hline $\begin{array}{l}\text { Kedelai } 5 \text { Baris }+ \\
\text { Diantara Var Bima } 2\end{array}$ & 24.42 bc & $24.06 \mathrm{de}$ & $1.80 \mathrm{f}$ & $49.69 \mathrm{~b}$ & $48.64 \mathrm{~b}$ & $2.15 \mathrm{e}$ \\
\hline $\begin{array}{l}\text { Kedelai } 5 \text { Baris }+ \\
\text { Diantara Var Nasa } \\
29\end{array}$ & $22.00 \mathrm{bc}$ & 21.53 def & $2.01 \mathrm{f}$ & $40.78 \mathrm{~cd}$ & $39.83 \mathrm{~cd}$ & $2.33 \mathrm{e}$ \\
\hline $\begin{array}{l}\text { Kedelai } 7 \text { Baris }+ \\
\text { Diantara Var } \\
\text { Pioneer } 35\end{array}$ & $20.11 \mathrm{c}$ & 19.03 ef & $5.24 \mathrm{a}$ & $37.42 \mathrm{df}$ & $35.92 \mathrm{df}$ & $4.11 \mathrm{c}$ \\
\hline $\begin{array}{l}\text { Kedelai } 7 \text { Baris }+ \\
\text { Diantara Var Bima } \\
19\end{array}$ & $30.75 \mathrm{abc}$ & $29.83 \mathrm{c}$ & $3.11 \mathrm{e}$ & $53.42 \mathrm{~b}$ & $50.98 b$ & $5.30 a b$ \\
\hline $\begin{array}{l}\text { Kedelai } 7 \text { Baris }+ \\
\text { Diantara Var JH } 27\end{array}$ & $46.64 \mathrm{a}$ & $44.53 \mathrm{a}$ & $5.06 a b$ & $48.78 \mathrm{bc}$ & $46.64 \mathrm{bc}$ & $4.90 \mathrm{~b}$ \\
\hline $\begin{array}{l}\text { Kedelai } 7 \text { Baris }+ \\
\text { Diantara Var Bima } 2\end{array}$ & $37.53 a b$ & $41.06 \mathrm{a}$ & $4.47 \mathrm{bc}$ & $73.33 \mathrm{a}$ & $71.14 \mathrm{a}$ & $3.99 \mathrm{c}$ \\
\hline $\begin{array}{l}\text { Kedelai } 7 \text { Baris }+ \\
\text { Diantara Var Nasa } \\
29\end{array}$ & $37.53 \mathrm{ab}$ & $35.83 b$ & $4.21 \mathrm{~cd}$ & $71.64 \mathrm{a}$ & $69.61 \mathrm{a}$ & $3.11 \mathrm{~d}$ \\
\hline BNT 5\% & 16,34 & 15,57 & 2,00 & 24,68 & 23,61 & 1,90 \\
\hline
\end{tabular}

Keterangan : Angka didampingi huruf yang sama pada kolom yang sama berarti tidak berbeda nyata menurut uji BNT $5 \%$.

Pada Tabel 2 diatas menunjukkan bahwa jumlah biji per tanaman tertinggi pada perlakuan kedelai ditanaman diantara jagung hibrida varietas Bima 2 dan Nasa 29 dengan jarak tanam kedelai 7 baris masing-masing 73,33 biji dan 71,64 biji. Sedangkan jumlah polong isi paling sedikit pada perlakuan kedelai ditanam diantara jagung varietas Pioneer 35 dangan jarak tanam kedelai 5-7 baris masing-masing $(31,28$ biji dan 37,42 biji) dan kedelai ditanam diantara jagung varietas $\mathrm{JH} 27$ dengan jarak tanam kedelai 5 baris $(37,17$ biji).

Data jumlah biji isi per tanaman pada Tabel 2 diatas menunjukkan pola yang sama dengan jumlah biji pertanaman. Jumlah biji isi per tanaman tertinggi pada perlakuan kedelai ditanam diantara jagung varietas Bima 2 dan Nasa 29 dengan jarak tanam kedelai 7 baris, masing-masing 71,14 biji dan 69,61 biji. Sedangkan jumlah biji isi per tanaman paling sedikit pada perlakuan kedelai ditanam diantara jagung varietas Pioneer 35 dengan jarak tanam kedelai 5-7 baris masing-masing 30,19 biji dan 35,92 biji, serta kedelai ditanam diantara jagung varietas $\mathrm{JH} 27$ dengan jarak tanam kedelai 5 baris $(35,31$ biji). Berdasarkan waktu tanam kedelai diantara tanaman jagung menunjukan bahwa kedelai ditanam 0-3 minggu sebelum tanam jagung mempunyai jumlah polong kering lebih tinggi (Turmudi, 2002). 
Pada Tabel 2 diatas menunjukkan bahwa presentase biji rusak per tanaman paling tinggi pada perlakuan kedelai ditanam diantara jagung varietas $\mathrm{JH} 27$ dengan jarak 5 baris kedelai $(5,87 \%)$, sedangkan presentase biji rusak per tanaman paling sedikit pada perlakuan kedelai ditanam diantara jagung varietas Bima 2 dan Nasa 29 dengan jarak tanam kedelai 5 baris, masingmasing $(2,15 \%$ dan $2,33 \%)$.

Hasil analisis ragam terhadap bobot 100 butir dan hasil produksi kedelai per ha berdasarkan ubinan tidak terdapat interaksi antara perlakuan penanaman kedelai diantara beberapa varietas jagung hibrida dengan jarak tanam 5-7 baris kedelai. Pada masing-masing perlakuan menunjukkan bahwa kedelai berpengaruh nyata terhadap bobot 100 butir dan hasil produksi kedelai. Sedangkan jarak tanam kedelai $5-7$ baris diantara beberapa varietas jagung hibrida tidak berpengaruh nyata pada perlakuan tinggi tanaman, bobot 100 butir, jumlah cabang per tanaman dan hasil produksi (Tabel 3).

Tabel 3. Rata-rata bobot 100 butir dan produksi kedelai akibat pengaruh perlakuan kedelai ditanam dianatara beberapa varietas jagung hibrida dan jarak tanam kedelai 5-7 baris.

\begin{tabular}{lcc}
\hline \multicolumn{1}{c}{ Perlakuan } & \multicolumn{2}{c}{ Variabel Pengamatan } \\
\cline { 2 - 3 } & Bobot 100 butir (g) & Produktivitas (kg/ha) \\
\hline Kedelai Diantara Var Pioneer 35 & $14,70 \mathrm{a}$ & $826,63 \mathrm{bc}$ \\
Kedelai Diantara Var Bima 19 & $12,40 \mathrm{~b}$ & $794,64 \mathrm{c}$ \\
Kedelai Diantara Var JH 27 & $13,47 \mathrm{ab}$ & $921,03 \mathrm{ab}$ \\
Kedelai Diantara Var Bima 2 & $14,67 \mathrm{a}$ & $941,14 \mathrm{a}$ \\
Kedelai Diantara Var Nasa 29 & $14,42 \mathrm{a}$ & $917,52 \mathrm{ab}$ \\
\hline BNT 5 \% & 1,41 & 101,40 \\
\hline Kedelai 5 baris & 13.17 a & $700,51 \mathrm{a}$ \\
Kedelai 7 baris & $14.69 \mathrm{a}$ & $1059,87 \mathrm{a}$ \\
\hline BNT 5 \% & tn \\
\hline Keterangan : Angka didampingi huruf yang sama pada kolom yang sama bearti tidak berbeda
\end{tabular}

Data bobot 100 butir pada Tabel 3 diatas tertinggi pada perlakuan kedelai ditanam diantara jagung hibrida varietas pioneer 35, Bima 2 dan Nasa 29 masingmasing $(14,70 \mathrm{~g}, \quad 14,67 \mathrm{~g}$ dan $14,42 \mathrm{~g})$, sedangkan bobot 100 butir terkecil pada tanaman kedelai ditanam diatara jagung varietas Bima $19(12,40 \mathrm{~g})$. Sedangkan kedelai ditaman dengan jarak 5-7 baris diantara beberapa varietas jagung hibrida tidak terjadi perbedaan pada bobot 100 butir.

Produktivitas tanaman kedelai diambil dengan cara ubinan yaitu untuk jarak kedelai 5 barislebar ubinan $(2,4 \mathrm{~m} \times 3,0 \mathrm{~m}=7,2 \mathrm{~m} 2)$ sedangkan kedelai ditanam 7 baris luas ubinan (3,0 m x 3,0 m = 9,0 m2). Hasil produksi kedelai tertinggi pada perlakuan kedelai ditanam diantara varietas jagung Bima 2 (941 kg/ha), sedangkan produktivitas terendah pada perlakuan kedelai ditanam diantara jagung varietas Bima 19 (794,64 $\mathrm{kg} / \mathrm{ha}$ ). Kedelai yang ditaman dengan jarak 57 baris diantara varietas jagung secara analisis statistic tidak berbeda terhadap hasil produktivitas kedelai (Tabel 3).

Bobot kering kedelai pada perlakuan pemangkasan jagung dengan menyisakan 4 daun di atas tongkol memberikan berat kering yang lebih tinggi dibanding perlakuan lainya namun tidak berbeda nyata. Hal ini diduga pada keadaan tersebut tanaman mampu mengabsorbsi energi matahari untuk digunakan dalam proses fotosintesis lebih baik dan mampu memanfaatkannya dengan lebih efisien sehingga berat kering yang dihasilkan juga akan lebih besar (Permanasari dan Kastono. 2012).

Kepadatan populasi pada tempat tumpangsari jagung kedelai menyebabkan produksi kedelai tertekan akibat kompetisi dengan tanaman jagung dengan hasil kedelai $59-75 \%$ lebih rendah dibandingkan dengan 
monokultur (Kipkemoi et al., 2002). ). Hal tersebut didukung oleh pendapat Lehar et al, (2017) menyatakan bahwa apabila jarak tanam yang lebih rapat dengan jenis komoditi yang berbeda akan terjadi kompetisi, akan tetapi penggunaan jarak tanam yang lebih rapat dengan komoditi yang sama dapat menekan suhu tinggi sehingga dapat memacu pertumbuhan tanaman dan hasil yang optimal. Ariel et al., 2013 melaporkan bahwa penanaman dengan tumpangsari jagung dengan kedelai pada rasio 1:1 menekan produksi pertumbuhan kedelai akibat dominansi tanaman jagung terhadap kedelai). Menurut Yuwariah et al., (2017), bahwa kedelai varietas Agromulyo tumpangsari dengan jagung mempunyai produksi $0,23-0,35 \mathrm{t} / \mathrm{ha}$.

Menurut Kamal (2011), Produksi tanaman pangan pada dasarnya dapat dipandang sebagai hasil dari suatu proses interaksi antara tanaman dan lingkungannya, sehingga kondusifitas lingkungan tumbuh dapat mengoptimalkan produksi tanaman sesuai potensi genetiknya. Dalam proses pertumbuhan dan produksinya, tanaman memanfaatkan sumberdaya yang ada disekitarnya atau factor lingkungan. Faktor ini terdiri dari cahaya, air, udara, unsur hara dan media tumbuh.

Menurut Warsana (2009), pada sistem tumpangsari sebaran sinar matahari merupakan hal yang sangat penting. Hal ini bertujuan untuk menghindari persiangan antar tanaman yang ditumpangsarikan dalam hal mendapatkan sinar matahari, selain itu perlu diperhatikan juga tinggi dan luas antar tajuk tanaman yang ditumpangsarikan. Tinggi dan lebar tajuk antar tanaman yang ditumpangsarikan akan berpengaruh terhadap penerimaan cahaya matahari, dan lebih lanjut akan mempengaruhi hasil sintesa (glukosa) dan muara terakhir akan berpengaruh terhadap hasil secara keseluruhan. Selain terjadi persaingan dalam penerimaan radiasi matahari tanaman tumpangsari juga berpengaruh terhadap penggunaan air dan unsur hara (Aminah et al., 2013).

Pola tanam tumpangsari untuk tanaman lebih rendah sebaiknya ditanam lebih dahulu kemudian disusul dengan tanaman yang memiliki ukuran batang lebih tinggi dengan umur lebih genjah, dengan tujuan untuk meminimalisir persaingan antar tanaman sejenis maupun lain jenis (Kriswantoro dan Hermanto. 2015). Produksi kedelai yang ditanam setelah tanaman jagung pada kombinasi perlakuan jarak tanam dengan pemberian pupuk hayati berbeda nayat dengan perlakuan 3 baris jagung dan 3 baris kedelai serta perlakuan 1 baris jagung 1 baris kedelai (Aminah et al., 2014). Biomassa tanaman erat kaitannya dengan komponen pertumbuhan vegetative tanaman. Jarak tanam yang rapat dan dengan populasi yang padat mengakibatkan cahaya matahari tidak dapat diserap tanaman dengan optimal sehingga terjadi kompotesi tanaman yang berakibat pada pertumbuahn tinggi tanaman, jumlah daun dan luas daun (Rulliyah. 2018).

\section{KESIMPULAN}

1. Tanaman kedelai dengan jarak tanam 7 baris diantara Jagung hibrida varietas $\mathrm{JH}$ 27 signifikan berpengaruh terhadap jumlah polong per tanaman dan jumlah polong isi per tanaman dibanding perlakuan lainnya.

2. Kedelai dengan jarak tanam 7 baris diantara jagung hibrida varietas Bima 2 dan Nasa 29 mempunyai jumlah biji per tanaman dan jumlah biji isi per tanaman berpengaruh signifikan dibanding perlakuan lainnya.

3. Kedelai ditanam diantara varietas jagung hibrida Nasa 29, JH 27 dan Bima 2 terjadi peningkatan produksi signifikan terhadap varietas Bima 19 sebesar $15,47 \%, 15,85 \%$ dan $18,36 \%$.

\section{DAFTAR PUSTAKA}

Aminah, I.S., D. Budianta, Y. Parto, Munandar dan Erizal. 2013. Tumpangsari Kedelai - Jagung, Jarak tanam, dan Pupuk hayati di Lahan Pasang Surut. Prosiding Seminar Nasional Hasil Penelitian Tanaman Aneka Kacang dan Umbi. 734-741.

Aminah, I.S., D. Budianta, Munandar, Y. Parto, dan Erizal. 2014. Tumpangsari Jagung (Zea mays L.) dan Kedelai (Glycine max L. Merrill) untuk Efisiensi Penggunaan dan Peningkatan Produksi Lahan Pasang Surut. J. Tanah dan Iklim Vol 38 (2) : 119-128.

Ariel, C.O., O.A. Eduardo, G.E. Benito, G. and Lidia. 2013. Effects of two plant 
arrangements in corn (Zea mays L.) and Soyben (Glycine max L. Merrill) intercropping on soil nitrogen and phosphorous status and growth of component crops at an Argentina Argiudoll. American Journal of Agriculture and Forestry 1(2):22-31.

Herliana., Atang dan I. Ujiono. 2015. Pengaruh Dosis Pemupukan Pada Sistem Tanam Tumpangsari Terhadap Pertumbuhan dan Hasil Jagung Manis dan Kedelai. J. Agroekotek. 7 (2) : 129 137.

Kamal, M. 2011. Kajian Sinergi Pemanfaatan Cahaya dan Nitrogen dalam Produksi Tanaman Pangan. Pidato ilmiah pengukuhan guru besar ilmu tanaman pada 23 Februari 2011. Penerbit Universitas Lampung.

Kipkemoi, P.L. Wasike, V.W. , Ooro, P.A., Riungu,T.C., Bor, P.K. and Rogocho, L.M. 1997. Effects of Intercropping Pattern on Soybean and Maize Yield in Central Rift Vlley of Kenya.

Khotbawan,I., H. Hawalid, dan R.I.S. Aminah. 2015. Pengaruh Jarak Tanam Dan Pemberian Pupuk Hayati Terhadap Pertumbuhan Dan Produksi Tanaman Kedelai (Glycine Max L. Merrill) Dan Jagung (Zea Mays L.) Dengan Pola Tanam Tumpang Sari Di Lahan Lebak. J. Klorofil. Vol (X) $2: 76-81$.

Kriswantoro, $\mathrm{H}$ dan Hermanto. Kajian Sistem Tumpangsari Jagung Manis dan Kedelai di Lahan Kering Kabupaten Musi Rawas. J. Lahan Suboptimal. Vol 2 (2) : $181-189$.

Lehar L., T. Wardiyati, M. D. Maghfoer, A. Suryanto. 2017. Influence of mulch and plant spacing on yield of Solanum tuberosum L. cv. Nadiya at medium altitude. International Food Research Journal 24(3): $1338 \quad-1344$. http://www.ifrj.upm.edu.my/24\%20(03)\% 202017/(60).pdf

Lihtourgidis A.S., C.A. Dorgas, C.A. Damalas, and D.N. Vlachostergios. 2011. Annual Intercrops: an alternative pathway for sustainable agriculture. Review Article. Australian Journal of Crop Science 5(4): 396-410.

Marliah, A., Jumini dan Jamilah. 2010. Pengaruh Jarak Tanam Antar Barisan Pada Sistem Tumpangsari Beberapa Varietas Jagung Manis Dengan Kacang
Merah Terhadap Pertumbuhan Dan Hasil. J. Agrista Vol. 14 (1) : 30 - 38.

Permanasari. I dan D. Kastono. 2012. Pertumbuhan Tumpangsari Jagung dan Kedelai Pada Perbedaan Waktu Tanam dan Pemangkasan Jagung. Jurnal Agroteknologi, Vol. 3 (1) : 13-20.

Rulliyah, Binti., D. Armita dan E. Nihayati. 2018. Pengaruh Perbedaan Pola Tanam Sistem Tumpangsari Pada Pertumbuhan Kedelai (Glycine max (L.) Merrill). J. Produksi Tanaman. Vol 6 (3) : 511-515.

Turmudi, E. 2002. Kajian Pertumbuhan dan Hasil Tanaman Dalam Sistem Tumpangsari Jagung dengan Empat Kultivar Kedelai Pada Berbegai Waktu tanam. Jurnal IImu-IImu Pertanian Indonesia. Vol 4 (2) : 89-96.

Warsana. 2009. Introduksi Teknologi Tumpangsari Jagung dan Kacang Tanah. Tabloid Sinar Tani. 25 Pebruari 2009. Jawa Tengah.

Yuwariah, Y., D. Ruswandi dan A.W. Irwan. 2017. Pengaruh pola tanam tumpangsari jagung dan kedelai terhadap pertumbuhan dan hasil jagung hibrida dan evaluasi tumpangsari di Arjasari Kabupaten Bandung. Jurnal Kultivasi Vol. 16 (3) : 514-521. 